\begin{tabular}{|c|c|c|c|}
\hline Article Info & \multicolumn{2}{|c|}{ RESEARCH ARTICLE $\quad$ ARAŞTIRMA MAKALESİ } & \\
\hline Title of Article & \multicolumn{2}{|c|}{$\begin{array}{c}\text { Cognitive Maps and Urban Equipment in } \\
\text { Urban Spaces: The Case of Trabzon } \\
\text { Meydan Park }\end{array}$} & \\
\hline $\begin{array}{l}\text { Corresponding } \\
\text { Author }\end{array}$ & \multicolumn{2}{|c|}{$\begin{array}{l}\text { İrem BEKAR } \\
\text { Karadeniz Teknik Üniversitesi Mimarlık Fakültesi, İç Mimarlık Bölümü, } \\
\text { irembekar@ktu.edu.tr }\end{array}$} & \\
\hline $\begin{array}{l}\text { Received Date } \\
\text { Accepted Date }\end{array}$ & \multicolumn{2}{|l|}{$\begin{array}{l}05.07 .2021 \\
01.12 .2021\end{array}$} & \multirow{4}{*}{$\begin{array}{l}\text { Kent Akademisi } \\
\text { Uriban Academy }\end{array}$} \\
\hline DOI Number & \multicolumn{2}{|c|}{ https://doi.org/10.35674/kent.962892 } & \\
\hline Author / Authors & $\begin{array}{l}\text { İrem BEKAR } \\
\text { Zeynep Nilsun KONAKOĞLU } \\
\text { Büşra BULUT }\end{array}$ & $\begin{array}{l}\text { ORCID: } 0000-0002-6371-9958 \\
\text { ORCID: } 0000-0002-1539-305 X \\
\text { ORCID: } 0000-0001-5364-8976\end{array}$ & \\
\hline How to Cite & \multicolumn{2}{|c|}{$\begin{array}{l}\text { Bekar, I., Konakoğlu, N.Z. and Bulut, B. (2021). Cognitive Maps and Urban } \\
\text { Equipment in Urban Spaces: The Case of Trabzon Meydan Park, Kent Akademisi, } \\
\text { Volume, 14, Issue 4, Pages,1100- } 1116 .\end{array}$} & \\
\hline
\end{tabular}

\title{
Kentsel Mekanlarda Bilişsel Haritalar ve Kent Donatıları: Trabzon Meydan Parkı Örneği
}

\begin{abstract}
:
Cities are social indispensables, which are the most important indicators of the political and social accumulation of societies. All of the urban values such as geographical location, climate, natural vegetation, buildings and structures that each city has constitute the identity of the city. One of the important reflectors of the urban identity is the urban spaces that have become the symbols of the city. Urban spaces that respond to various needs of ccitizens are important elements in terms of urban with the values they have and the furnishings that exist in them. While describing these urban spaces that have a place in their minds, citizens sometimes get help from a memory they live, from a building they see, and sometimes from an urban equipment that they use or that attracts their attention. Cognitive maps formed by the combination of these different concepts have an important place in describing the environment of the individual and determining location, distance and place information. The cognitive map, which is shaped in the mind of the individual in line with his/her cultural characteristics, lifestyle and experiences, is an important method that enables the coding of mental processes such as remembering/remembering, storing, acquiring information, solving, accumulating and so on. It is an important method that provides the coding of mental processes such as In this study, the urban equipment in Trabzon Meydan Park is determined and the contribution of the urban equipment to the urban
\end{abstract}

${ }^{1}$ Karadeniz Teknik University, Faculty of Architecture, Department of Interior Architecture irembekar@ktu.edu.tr

${ }^{2}$ Avrasya University, Engineering and Architecture Faculty, Department of Interior Architecture nilsun.konakoglu@avrasya.edu.tr

${ }^{3}$ Ostim Teknik University, Vocational School, Multi-dimensional Modelling and Animation Programme busra.bulut@ostimteknik.edu.tr 
identity and the cognitive map are determined through the urban equipment, together with the questionnaire applied to the citizens. In this direction, the data obtained through the survey and on-site detection studies were interpreted. As a result, it has been revealed that the urban equipment of Meydan Park, which has an important place in the history of Trabzon, especially the Atatürk Statue and the memories of the park are important in determining the cognitive map.

KEYWORDS: Urban equipment, cognitive map, urban identity, city image, Trabzon Meydan Park

\section{ÖZ:}

Kentler toplumların siyasi, sosyal ve toplumsal birikimlerinin en önemli göstergeleri olan toplumsal vazgeçilmezlerdir. Her kentin sahip olduğu coğrafi konum, iklim, doğal bitki örtüsü, binalar, yapılar gibi kentsel değerlerin bütünü kentin kimliğini oluşturmaktadır. Kent kimliğinin önemli yansıtıcılarından biri de kentin simgesi haline gelmiş kentsel mekanlardır. Çeşitli gereksinimlere cevap veren kentsel mekanlar sahip oldukları değerler ve içlerinde var olan donatılarla kent mimarisi açıdan önemli birer unsur konumundadırlar. Kentliler zihinlerinde yer edinen bu kentsel mekanları tarif ederken bazen yaşadığı bir anıdan, gördüğü bir binadan bazen ise kullandığı veya dikkatini çeken bir kent donatısından yardım almaktadır. Birbirinden farklı bu kavramların birleşimi ile oluşan bilişsel haritalar bireyin çevresini tarif etmesinde, konum, uzaklık ve yer bilgilerinin belirlenmesinde önemli yere sahiptir. Bireyin kültürel özellikleri, yaşam biçimi ve deneyimleri doğrultusunda zihninde şekillenen bilişsel harita; hatırlama/anımsama, saklama, bilgi edinme, çözme, biriktirme vb. gibi zihinsel süreçlerin kodlanmasını sağlayan önemli bir yöntemdir. Bu çalışmada Trabzon Meydan Parkı'nda bulunan kent donatıları tespit edilerek kullanıcılara uygulanan anketle birlikte kent donatılarının kent kimliğine katkısı ve bilişsel haritanın kent donatıları üzerinden tespiti yapılmaktadır. Bu doğrultuda yapılan anket ve yerinde tespit çalışmaları ile elde edilen veriler yorumlanmıştır. Sonuç olarak bireylerin Trabzon tarihinde önemli bir yeri olan Meydan Parkı'nın kent donatılarının özellikle de Atatürk Heykeli'nin ve parka dair belleklerinde yer edinen anılarının bilişsel haritanın belirlenmesinde önemli olduğu ortaya konulmuştur.

ANAHTAR KELIMELER: Kent donatısı, bilişsel harita, kent kimliği, kent imgesi, Trabzon Meydan Parkı

\section{GİRiş:}

Tarihsel süreç içerisinde ortaya çıkan kentler, içinde bulundukları coğrafyanın şartlarını ve içinde yaşayan insanların kültürel niteliklerini benimseyerek sürekli bir gelişim içerisinde bulunmaktadırlar. Gelişen ve değişen kentler küreselleşmenin etkisiyle birlikte hızlı bir şekilde birbirine benzemekte, bu durum da kent kültürünü ve kent kimliğini olumsuz olarak etkilemektedir. Oysaki kentlerin sosyal, kültürel ve toplumsal birikimlerinin bütününü oluşturan kent kimliğinin yaşatılması kent-toplum-kültür arasındaki ilişkiyi doğru anlamaktan ve yaşatılmasından geçmektedir. Kentlerin önemli bileşenlerinden birisi olan kentsel mekanlar, bu ilişkinin en çok hissedildiği ve insanların hem kendileri hem de çevreleri ile ilişkide bulunduğu alanlardır. Bellek ile ilişkilendirilen bu alanlar kent kimliğinin oluşmasına yardımcı olan etmenlerin birçoğunu içerisinde barındırmakta ve akıllarda kalan soyut-somut pek çok unsurla birlikte bilişsel (zihinsel) bir harita oluşturulmasına yardımcı olmaktadır. Bu alanlar içerisinde yer alarak, kimi zaman taşıdığı fiziksel özellikleri ile kimi zamansa anlamsal değeri veya anı niteliği ile ön plana çıkan, kentlerin kendilerine özgü kimliklerinin yansitılması konusunda kent donatıları önemli bir yere sahiptir. Bir kenti daha algılanabilir kılan kent donatıları, bireylerin görsel ve fiziksel olarak kentle kurdukları ilişkinin somut yansımalarıdır. Birey açısından farklı bir anlam ve öneme sahip olan kent donatıları, kent açısından da bulundukları çevreyi tanımlaması nedeniyle önemlidir. Kentin bir öğesi haline gelen kent donatıları içinde bulundukları çevreyle bütünleşmesinden ötürü kent kimliğinin oluşmasında önemli birer araçtır (Bayraktar ve ark., 2013; Eray \& Kutlu, 2021). Kent donatıları bulunduğu mekânda bir imge olarak ön plana çıkabilmekte ve bulunduğu mekânı tanımlayarak mekâna özgü bir imge olarak akılda yer edinebilmektedir.

Bu çalışmada Trabzon Meydan Parkı'nda bulunan kent donatılarının tespiti yapılmakta ve kullanıcılara uygulanan anketle birlikte kent donatılarının kent kimliğine katkısı ve bilişsel haritanın kent donatıları üzerinden tespiti yapılmaktadır. Çalışmanın ilk kısmında kentsel bilişsel haritalar ve kent donatılarının açıklamaları yapılarak kentlerle olan ilişkisi açıklanmıştır. Ardından Trabzon Meydan Parkı'nda yer alan kent donatılarını sınıflandırılmış ve her bir kategoriye ait kent donatıları tiplere ayırılarak açıklamaları yapılmıştır. Çalışmanın ikinci kısmında anket çalışmasının değerlendirilmelerine yer verilmiştir. Kullanıcıların kent donatılarına ait algı ve düşünceleri belirlenip grafiklerle sunulmuştur. 
Mevcutta, kentsel alanların kullanıcılar üzerindeki bilişsel etkisini konu alan çeşitli çalışmalar bulunmaktadır. Öztürk (2016) çalışmasında, Eskişehir kent belleğinin oluşmasında, kent öğelerinin bellekle olan ilişkisini değerlendirerek kentsel mekân öğelerini saptamıştır. Çalışmasında gelişen ve değişen kent belleği imgelerini bilişsel haritalar aracılığıyla incelemiştir. Arruba vd. (2016) yaptığı araştırmada kent donatılarının kent kimliği ile ilişkisini inceleyerek, kent mobilyalarının kamusal alanı tanımlama ve tamamlamadaki önemini vurgulamış ve kentsel peyzaja müdahale etme biçimlerini incelemiştir. Türk (2017) ise çalışmasında Beypazarı kent kimliğini oluşturan elemanları ortaya çıkararak, kentsel kimliğin kentin yaşayanları tarafından imgelenebilirlik düzeylerinin zamanla değişimini incelemiştir. Südaş ve Öz (2018), Ege Üniversitesi kampüsünü çalışma alanı olarak belirleyerek, bilişsel haritaların kullanıcılara göre değişimini incelemiştir. Bu çerçevede mekânsal bağlamın farklı gruplara göre çeşitliliği saptanmıştır. El-Ghonaimy (2020) Bahreyn kent kimliğini canlandırmada kent mobilyalarının etkisini incelediği araştırmasında kent donatılarının kentin kimliğini vurgulayacak yönde tasarlanması gerektiğine dikkat çekmiştir. Bu noktada sokakların tasarımında ve mobilya elemanlarının seçiminde fiziksel unsurlar, kültürel özellikler, sosyo-ekonomik faktörler, tarihsel boyut, biçimsel faktörler, ideoloji ve tutarlılık faktörlerinin göz önünde bulundurulması gerektiğini savunmuştur. Bekar ve Ertaş (2021) ise kent mobilyalarının tarihsel çevre kimliğinin oluşumundaki yerini ve tarihi çevre içerisinde kent mobilyalarının sahip olması gereken özellikleri irdelemiştir.

Literatürde incelenen çalışmalar genellikle kent donatılarının kent kimliği oluşturmadaki yerini, kentsel mekanların zaman içerisindeki değişimlerinin bilişsel haritalar yöntemiyle ortaya çıkarılmasını ve kullanıcılara göre bilişsel haritaların çeşitliliği kapsamındadır. Ancak, kent imgesi olarak kent donatılarının sınıflandırılarak kullanıcılar üzerindeki bilişsel etkisini Trabzon örneğinde inceleyen bir çalışmanın olmaması sebebiyle bu çalışma önem arz etmektedir ve benzer konudaki yeni çalışmalara referans olacağı düşünülmektedir.

\section{Kentlerde Bilişsel Haritalar}

"Bilişsel harita" kelimesini doğru anlamak ve anlamlandırmak için önce biliş ve harita kelimelerinin özüne inmek gerekmektedir. Biliş, insanların karmaşık sorunları algılaması, basitleştirmesi ve anlamlandırması sürecindeki zihinsel modelleri ifade etmek için kullanılmaktadır (Strati, 1998). Harita ise bir alanı, bu alan içindeki en önemli unsurları ve unsurların birbirleri ile olan ilişkilerini ortaya koyan görsel bir temsildir (Huff, 2002). Bilişsel haritalar, bireyler tarafından gerçek değer olarak belirlenen ve bireylerin yaşadıkları kentleri nasıl algıladıklarını ortaya koyan, kentler hakkındaki imajların belirlenmesine yardımcı olan belgelerdir. (Lloyd, 1997; Ülkeryıldız ve ark., 2009). Fiziksel çevrenin bir çeşit modeli veya temsili olan bilişsel harita kavramı başka bir deyişle, algı girdilerinin zihinde toplandıktan sonra bireyler tarafından geri çağırılmaları ile elde edilen replikasyonlar olarak da tanımlanabilmektedir (Jacobson, 1998). Bu bağlamda bilişsel haritaların; okunaklı mekanların oluşturulmasında oldukça önemli bir kavram olduğu ve bireylerin yaşadıkları çevreleri algılamalarında etkili olduğu ortaya konmuştur (Topçu \& Topçu, 2012; Türk, 2017). Şekil 1'de bireylerin çevreleri hakkında topladıkları bilgilere dayanarak algı süzgecinden geçen mekânsal alanlara dair çizilen bilişsel haritalar yer almaktadır. 


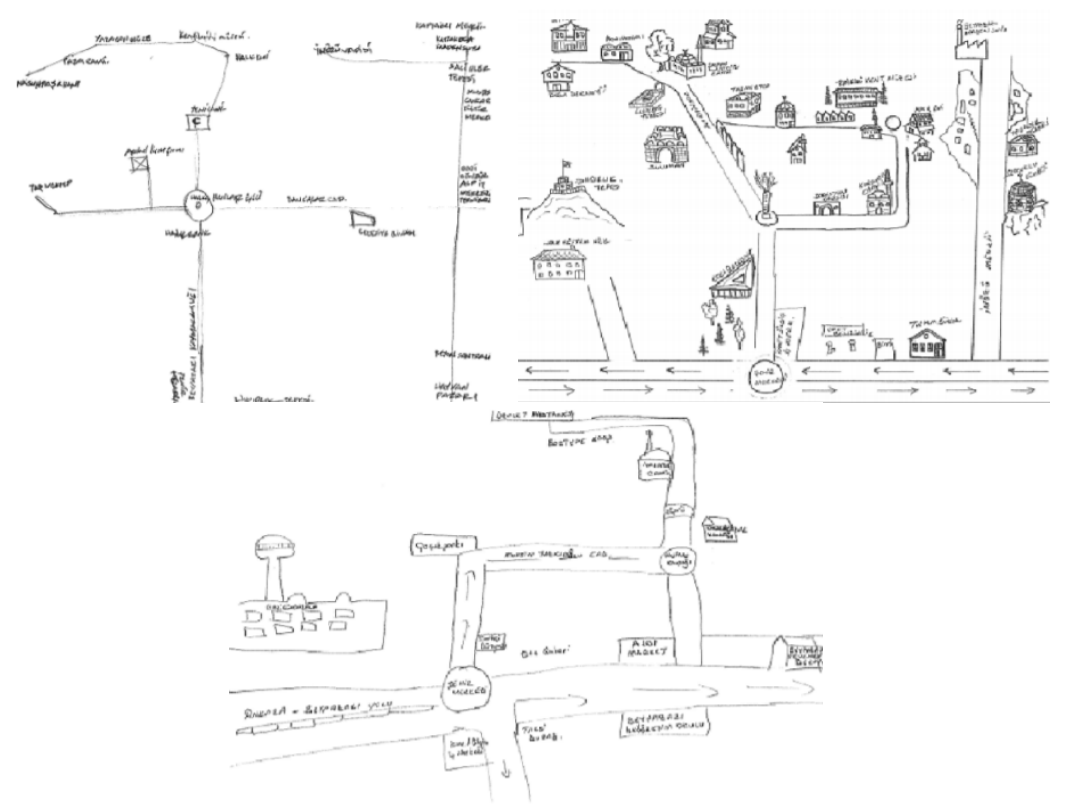

Şekil 1. Bilişsel Haritalara Örnekler (Türk, 2017)

Bilişsel haritalar kentsel imgeler sonucunda zihinde yaratılır ve kentsel imgelerde meydana gelen değişimlerden doğrudan etkilenir. Bilişsel haritalama süreci ve insanların fiziksel çevredeki değişkenleri ve göreli olarak mekân ile ilgili bilgiyi elde ettikleri, kodladıkları, depoladıkları, anımsadıkları ve çözdükleri bir süreçtir (Moore \& Golledge, 1976) ve mekânsal yönelme, hareket etme ve hatırlama ile bağlantılıdır (Sanoff, 1991; Yaylalı, 1998). Bütün bu fiziksel ve psikolojik bilgi-işleme etkinlikleri insanların o çevreye ilişkin çeşitli nitelikteki imgeleri, zihinsel haritaları ve bilişimleri bir araya getirebilmesine imkân tanımaktadır (Altman \& Chemers, 1980). Bilişsel haritalar fiziksel ortama ait her türlü bilgiyi toplama, analiz etme ve sunmaya ilişkin eylemlerin tümünü içermektedir (Özdağoğlu, 2010). En geniş tanımı ile "bireyin günlük yaşantısında karşılaştığı mekansal çevrede edindiği göreceli konumların ve olgusal niteliklerin kazanıldığı, depolandığı ve hatırlandığı bir dizi psikolojik dönüşümün bir araya gelmesiyle oluşan bir süreç" olarak açıklanabilir (Ülkeryıldız ve ark., 2009). Kentsel alanlarda kalitenin artırılması için mekanın algılanabilirliği ve okunaklılığı önem taşımaktadır (Çınar \& Çermikli, 2019). Mekanın ve mekândaki diğer öğelerin okunaklılığının ölçülebilmesinin en iyi yollarından biri de; ziyaretçinin_ihtiyaçları, tercihleri, kullanım amacı, kişisel özellikleri ve davranışlarının bir sonucu olarak ortaya çıkan bilişsel haritalardır.

Bilişsel harita çevreden gelen bilgide algılayan bireyin özelliklerine göre seçiciliğini yönlendiren zihinsel bir yapıdır. Bu nedenle bireyin çevresini betimlemek için kullandığı kavramsal değişkenler kişinin zihinsel imgesine göre farklılık göstermektedir. Bireyin doğduğu andan itibaren geliştirmeye başladığı zihinsel süreçlerin oluşturduğu düzen; bulunduğu topluma, sahip olduğu kültüre, yaşamış olduğu deneyimlerine, öğrenim düzeyine göre birbirinden farkl1lık göstermektedir (Çanakçığlu, 2011). Zihinsel imgenin belirlenmesinde kişinin çevreyi algılayışı, zihninde oluşan imaj ve bilişsel kurgu doğrudan etkili olmaktadır. Örneğin bir mimarın ve bir taksi şoförünün sokakları, caddeleri, parkları ve diğer kentsel alanları algılama biçimleri birbirinden farklılık gösterir. Taksi şoförü daha çok sokakların genişliğine, birleşim noktalarına ve yollara dikkat ederken bir mimar için sokaktaki yapıların detayları daha önemlidir (Yaylalı, 1998). Bilişsel haritalar, kişinin bireysel özelliklerine bağlı olarak belirli bir alanla ilgili kavramlarını ve bu kavramlar arasındaki ilişkileri aktarmaktadır (Miles \& Huberman, 1994).

Bilişsel haritalar; hafizadan alınmış bilgilerle beslenmekte ve haritayı şekillendiren bilgiler uzun vadeli bellekte korunmaktadır. Bir yeri hatırlamak için güçlü bir ipucu görevi üstlenen bilişsel haritalar; ilgili mekânda yaşanmış, deneyimlenmiş olayları ve yaşam boyu başımızdan geçen her türlü yaşantının depolandığı bellek olarak zihinde çağrışım yapılmasına yardımcı olmaktadır (Gattis, 2001). Anılarla ilişkilendirilen haritalar fiziksel çevreye ait konum, uzaklık ve yer bilgilerinin zihinde oluşturulmasına, anımsanmasına yardımcı olarak neyin neyle ilişki olduğuna dair kullanicilara ipucu vermektedir. 
Algının eyleme ve etkinliğe bağlı bir konu olması, kişinin daha çok kullandığı ve yararlandığı bir nesne ile ilişkili olması, o etkinliğe veya nesneye ilişkin uyaranların daha hızlı algılanmasına ve zihinsel şema oluşmasına neden olur (Gür, 1996). Nesne ile ilişkilendirilen kavramlar bilişsel haritalarda kullanılan kavramlardan daha geniş anlamlar barındırmaktadır (Mellado, 1997). Yollar, binalar gibi kent içerisinde yer alan donatılar da sahip oldukları fiziksel özellikler ve kişinin zihninde yer edinen anılarla birlikte bilişsel haritalarda yerini almaktadır.

\subsection{Kent İmgesi Olarak Kent Donatıları}

Kentsel ölçekte bileşenler çoğunlukla mekanı oluşturan sabit elemanları, öğeler ise bir bütünün hareket edebilen parçaları olarak tanımlanmaktadır (Özdemir ve ark., 1991). Bu kapsamda Lynch (1960), söz konusu zihinsel haritaların, yani kentin imgesel bileşenlerinin beş ana unsurdan oluştuğunu belirtmektedir. Bunlar yollar (insanların şehir içinde hareket ettiği yollar), kenarlar/sınırlar (süreklilik arz eden kısımlar), bölgeler (ortak özelliklerle karakterize alanlar), düğüm/odak noktaları (kavşaklar vb.), işaret ögeleri (dışsal rehber/ikonik noktalar)'dır. Kentsel öğeler ise hareket ve değişim gösterebilme özelliği nedeniyle kent mobilyaları kapsamında ele alınmıştır (Ertaş ve ark., 2017) (Şekil 2).

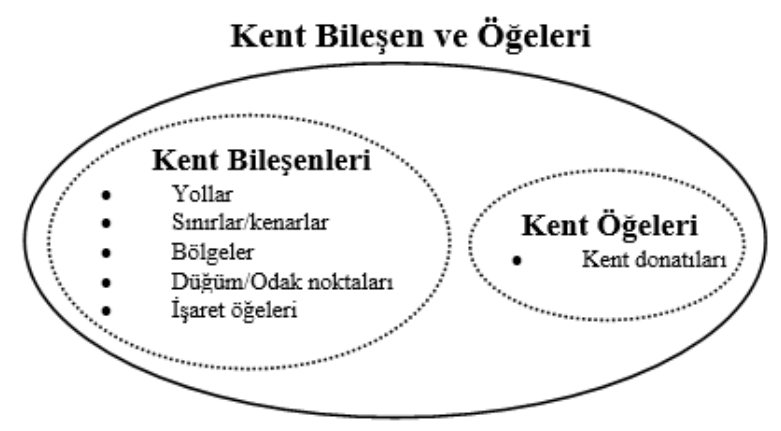

Şekil 2. Kent bileşen ve öğeleri (Ertaş ve ark., 2017)

Kent donatıları, yaşadığımız çevrede sokak, yol, meydan, cadde, park ve bahçe gibi kentsel alanlarda kullanıcıların ihtiyaç duyduğu konfor, eğlence, bilgi edinme gibi ihtiyaçlara karşılık veren ve daha iyi kullanılmasını sağlayan elemanlardır. Başka bir ifadeyle kentsel alanları işlevsel kılan veya işlevlerini olması gerektiği gibi uygulamalarını sağlayan nesnelerin tümüdür (Özaydın ve ark., 1991). Ayrıca binalar, iş merkezleri gibi kişisel kullanımlara ayrılan alanlarla çevrili yerlerde, mekânın kullanım açısından canlandırılarak zenginleştirilmesi ve doğal olmayan çevrenin kullanıcılar üstündeki ruhsal baskı tesirlerinin azalması noktasında da önemli kaynaklardır (Aykut, 1997). Kent sakinlerinin yaşamını kolaylaştıran, kullanıcılar arasındaki iletişimi sağlayan ve güçlendiren, kullanıldığı yerde estetik ve kullanım açısından anlamlar kazandıran, mekânı tanımlayan, sınırlandıran ve tamamlayan (Bayrakçı, 1991) kent donatıları kentsel yaşamın kalitesinin artırılmasında önemli bir rol üstlenmektedir. Kent mobilyaları hem işlevsel açıdan olduğu kadar görsel açıdan da önemli bir rol üstlenmektedir (Bekar \& Ertaş Beşir, 2021). Görsel anlamda sembolik, anlamsal, anıtsal ve estetik olarak betimlenen kent mobilyaları bulundukları çevreyi olumlu yönde etkileyerek (Aksu, 2013) çevreye görsel açıdan zenginlik katmaktadır.

Uzun yıllar boyunca konuyla ilgili uzmanların araştırmalarına konu olan kent donatıları farklı araştırmacılar tarafindan kullanım türü, işlevleri, teknik donatısı, kamu alanlarının dekorasyonu, yerleştikleri yere göre çeşitli şekillerde sınıflandırılmıştır. Yıldızcı (2001) kent donatılarını, işlevlerine göre; "zemin kaplamaları, oturma birimleri, aydınlatma elemanları, işaret ve bilgi levhaları, sınırlandırıcılar, su ögesi, üst örtü ögeleri, satış birimleri, sanatsal objeler, oyun alanı elemanları ve diğer ögeler" şeklinde incelemiştir. Çubuk (1991) ise kent donatılarını kentsel mekâna yerleştiriliş amacına göre; "koruma amaçlı, bilgi verme amaçlı, işaret verme amaçlı, süsleme amaçlı, barındırma amaçlı, eğlenme, oyun ve dinlenme amaçlı, satış ya da alışveriş amaçlı" şeklinde sınıflandırılmaktadır.

Kent donatıları doğru kullanıldığında kentin bir parçası olma, bulunduğu yeri öne çıkarma gibi görevler üstlenerek kent kimliğinin oluşumuna katkı sağlayabilmektedir. Öncelikli amacı kullanıcıların ihtiyaçlarına cevap vermek olsa da kent donatıları; zamanla kentle bütünleşen, kentlere anlam katan ve kimliğini yansıtan bir imge haline gelmektedir. 
Londra'daki telefon kabinleri, Paris'teki metro girişleri, Barselona'daki sokak lambaları, Prag'daki saat kulesi bulunduğu kentin kimliğinin belirlenmesinde etkili rol oynayan kent donatılarına örnektir (Şekil 3).
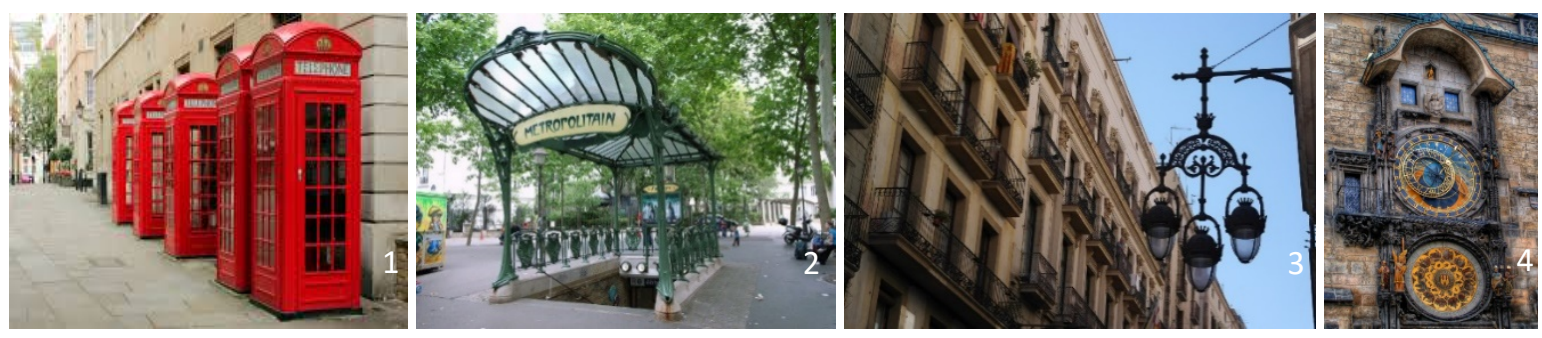

Şekil 3. 1-Londra'daki telefon kabinleri (URL-1), 2-Paris'teki metro girişleri (URL-2), 3-Barselona'daki sokak lambaları (URL-3), 4-Prag'daki saat kulesi (URL-4)

Kentsel imge olarak kent donatıları, sembolik işlevi sayesinde mekânı kullanan insanlar ile etkileşime girerek güçlü bağlantılar üretmektedir. Kullanıcı ve çevresi arasında iletişim kuran kent donatıları mekâna ait kültürel, sosyal, ekonomik özelliklere göndermeler yapan, anlam taşıyıcılar olarak da ön plana çıkmaktadır (Celbiş, 2001). Kent donatıları aracılığıyla kentsel mekanlarda birliktelik ve bütünlük duygusu oluşur ve zihinsel yansımalarla paylaşılır. Böylece kentsel biliş haritaları oluşumunda kent mobilyaları çevre ve bireyler arasındaki ilişkide etkin bir rol oynar. $\mathrm{Bu}$ nedenle kent donatılarının doğru tasarlanması, konumlanması çevresi ile hem işlevsel hem görsel açıdan uyum içerisinde olması kent, kentli, kent belleği, kent kimliği ve peyzaj mimarlığı meslek disiplini açısından oldukça önemlidir.

\section{Materyal ve Yöntem}

Trabzon Merkez'de yer alan ve kent kimliğinin oluşmasında etkili olan Meydan Parkı'nın kentlinin belleğinde yer edinen bilişsel haritasının ve kent donatılarının belirlenmesi adına yapılan çalışma iki aşamada gerçekleştirilmektedir. Çalışmanın ilk aşamasında Meydan Park'ındaki kent donatılarının tespitini gerçekleştirmek üzere yerinde tespit ve fotoğraflama tekniklerinden yararlanılmaktadır.

Çalışmanın ikinci aşamasında Meydan Parkı'nı kullanan katılımcılara anket çalışması uygulanmıştır. Anket çalışmasında kullanıcıların parkı kullanım sıklığı ve amacı tespit edilmiştir. Ayrıca park içeresinde yer alan ve kullanıcıların zihinlerinde yer edinmiş kent donatıları ve bu donatıların kent kimliğine katkılarının ölçülmesi amacıyla sorular yönlendirilmiştir. Böylece kentlinin gözündeki meydan parkının bilişsel haritasında kent donatılarının yeri belirlenmiştir. Toplamda 7 sorudan oluşan ve yaklaşık 10 dakika süren anket çalışması tamamlanmıştır. Anketler zaman kısıtı ve iklim koşulları nedeniyle 2021 yılı haziran ayında basit tesadüfi örnekleme yöntemi ile uygulanmıştır. Çalışmada 185 adet anket formu değerlendirilmiştir ve sonuçlara ulaşılmıştır.

\section{1.Çalışma Alanı}

Trabzon köklü bir tarihi geçmişe sahip, birçok farkı medeniyete ev sahipliği yapmış, coğrafi konumu ve kültürel özellikleri ile geçmişten günümüze ilgi gören ve ziyaret edilen bir kenttir. Trabzon, Doğu Karadeniz Bölgesi’nde tam bir geçiş noktasında konumlanmaktadır. Trabzon kenti doğal mirası, kültürel özellikleri ve birçok simgesel özelliği ile kent kimliğini oluşturmaktadır (Bayramoğlu \& Yurdakul, 2019). Trabzon kent kimliğinin tanımlanmasında önemli yerlerden biri olması nedeniyle çalışma alanı olarak seçilen Meydan Parkı, Trabzon'un Ortahisar ilçesinde, şehrin merkezinde, Atatürk Alanı sınırları içerisinde yer alan bir parktır (Şekil 4). 


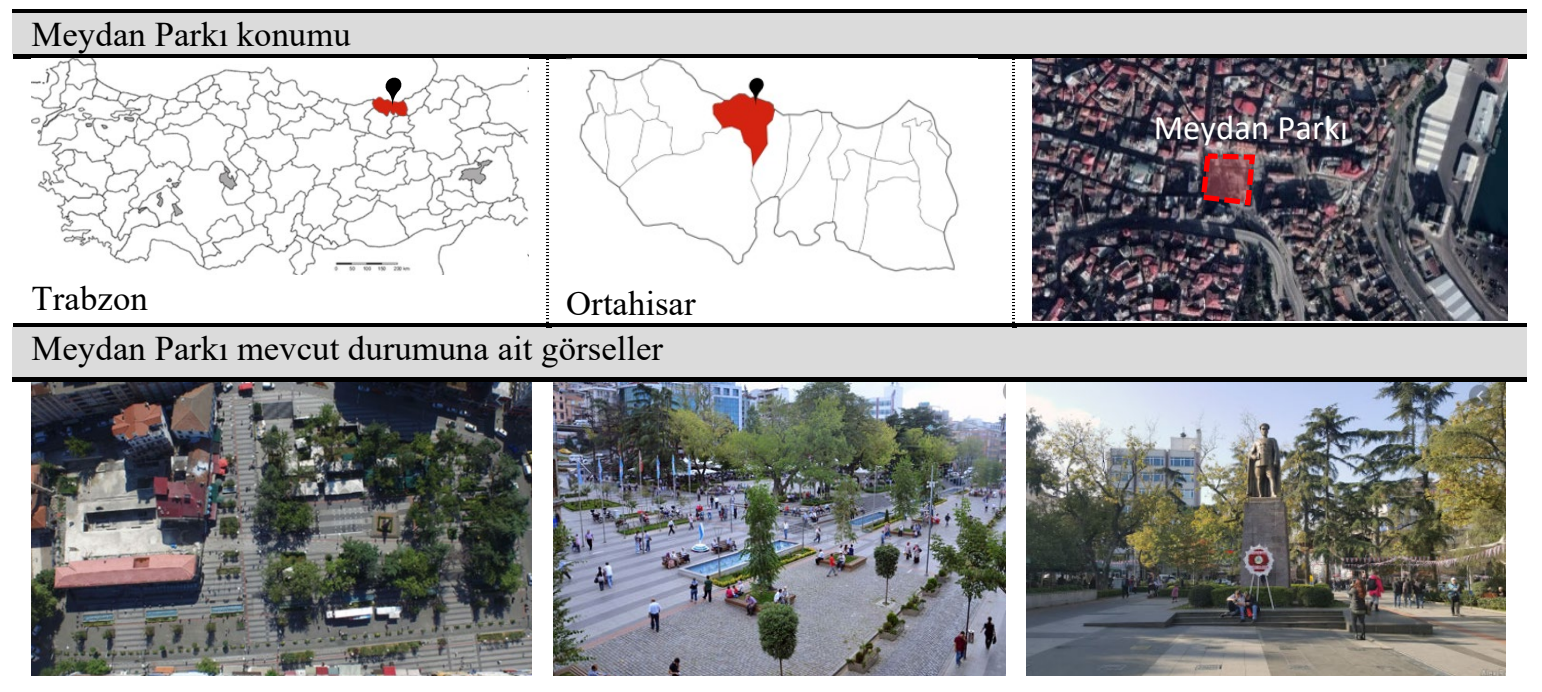

Şekil 4. Meydan Parkı konumu ve mevcut durumu

Meydan Parkı merkezi konumu ve sunduğu imkanlar açısından kentliler tarafından sıkılıkla kullanılan bir alandır. Dört tarafı caddelerle çevrili parkın yakın çevresinde alışveriş mekanları, restoranlar ve iş merkezi, oteller gibi çeşitli işlevlere hizmet veren mekanlar bulunmaktadır. Kentin merkezinde her yaş grubunun kullandığ 1 yoğun bir sirkülasyona sahip olan Meydan Parkı; Trabzon kenti için simgesel bir mekân haline gelmiştir. Meydan parkı; resmî törenlere ev sahipliği yapmakta ve oturma, dinlenme, yeme-içme, sohbet etme, sosyalleşme, eğlenme amaçlı rekreatif etkinliklerin gerçekleştirilmesine hizmet etmektedir. Parkın içerisinde yeme-içme mekânları, Atatürk heykeli, su havuzları, oturma birimleri, örtü elemanları, simgesel objeler, çöp kutuları, oturma basamakları ve merdivenler yer almaktadır (Kurdoğlu ve ark., 2018).

\section{Bulgular}

Çalışmanın bu bölümünde; Meydan Parkı'ndaki kent donatılarının yerinde gözlem yöntemi ile tespiti ve kullanıcılar ile yapılan anket çalışması verilerinin, tablolar ve grafikler üzerinden yorumlamaları yapılmaktadır.

\subsection{Meydan Parkı'ndaki Kent Donatılarının Tespiti}

Kent imgesi olarak kent donatıları başlığı altında incelenen çalışmalarda kent donatılarına ait çeşitli sınıflandırılmaların olduğu görülmektedir. Bu çalışma kapsamında kent donatıları; oturma elemanları, çöp kutuları, aydınlatma elemanları, döşemeler, bilgi ve yönlendirme levhaları, su öğeleri, heykeller, simgesel objeler, üst örtü öğeleri ve diğer öğeler olmak üzere on başlıkta ele alınmıştır.

Yerinde gözlem ve tespit çalışması sonucunda Meydan Park'ında yer alan kent donatıları tür ve tiplerine göre aşağıda sınıflandırılmaktadır (Tablo 1). Parkta 4 tip oturma elemanı, 4 tip çöp kutusu, 1 tip aydınlatma elemanı, 3 tip döşeme, 3 tip bilgi ve yönlendirme levhaları, 3 tip su öğesi, 1 tip heykel, 2 adet simgesel objeler, 1 adet üst örtü öğesi ve diğer öğeler bulunmaktadır. Tablo 1'de tür ve tiplerine göre sınıflandırılan kent donatıların Meydan Parkı içerisindeki konumlarının sembolik gösterimi Şekil 5'de verilmektedir. 
Tablo 1. Meydan Parkı kent donatıları

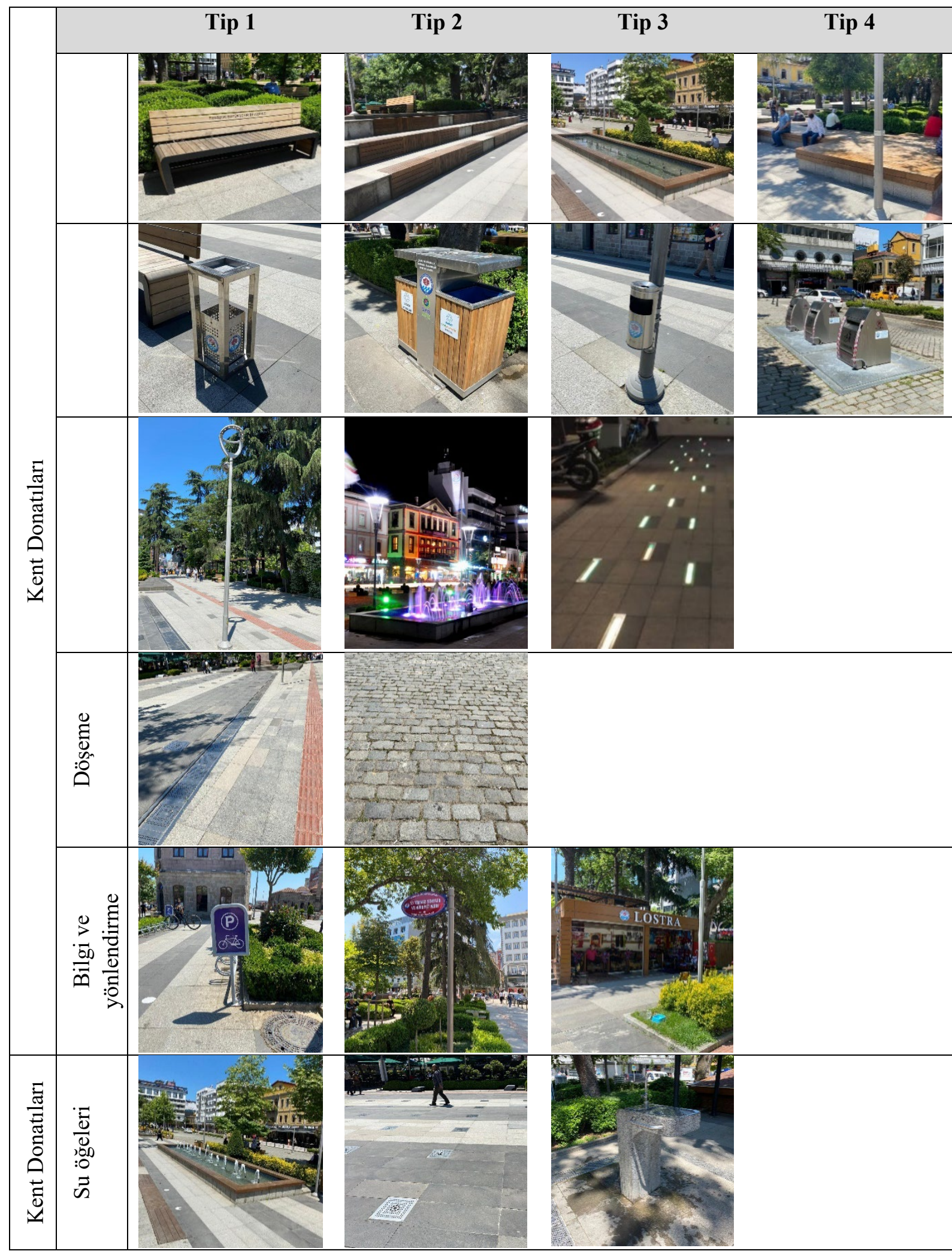




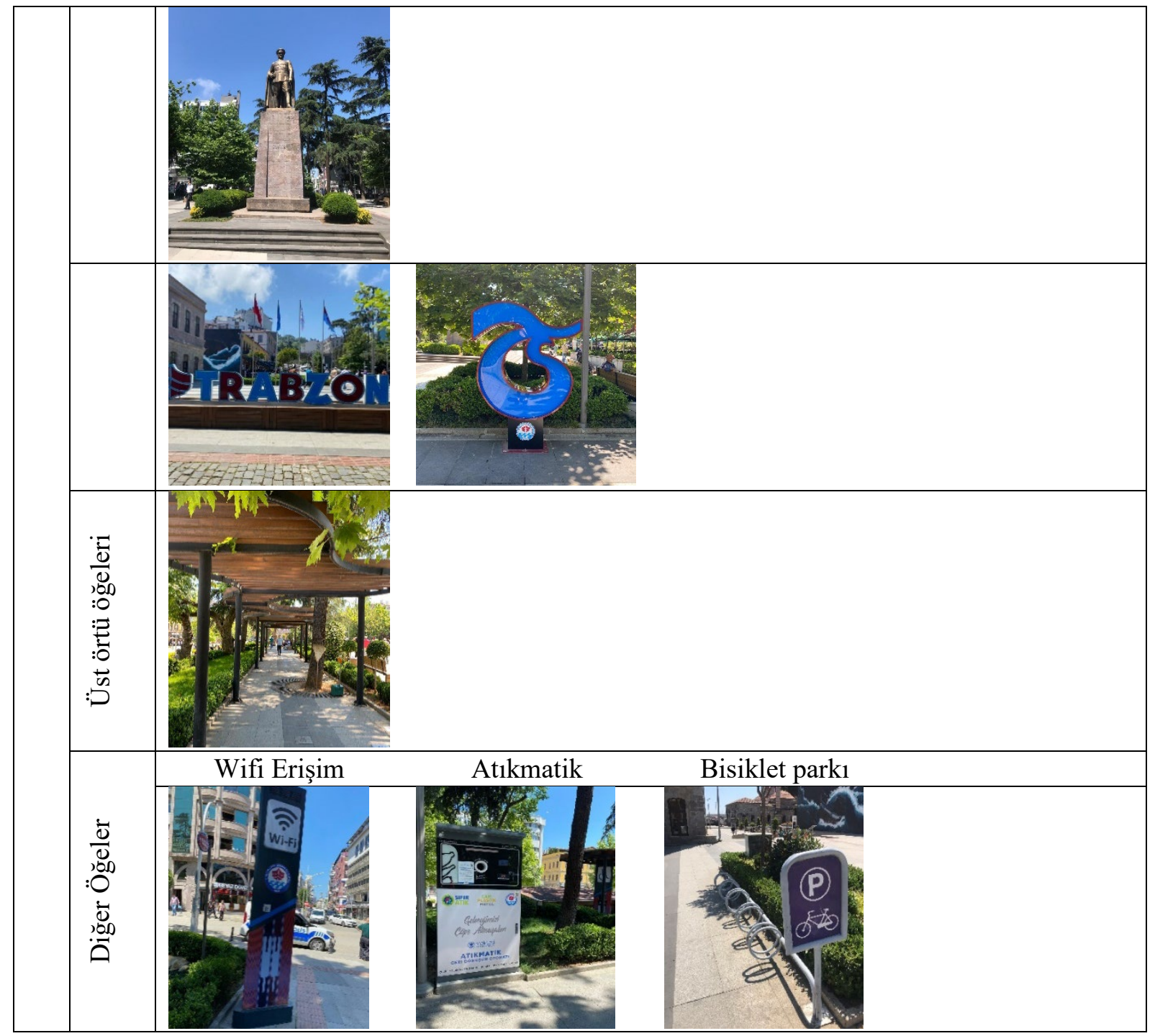




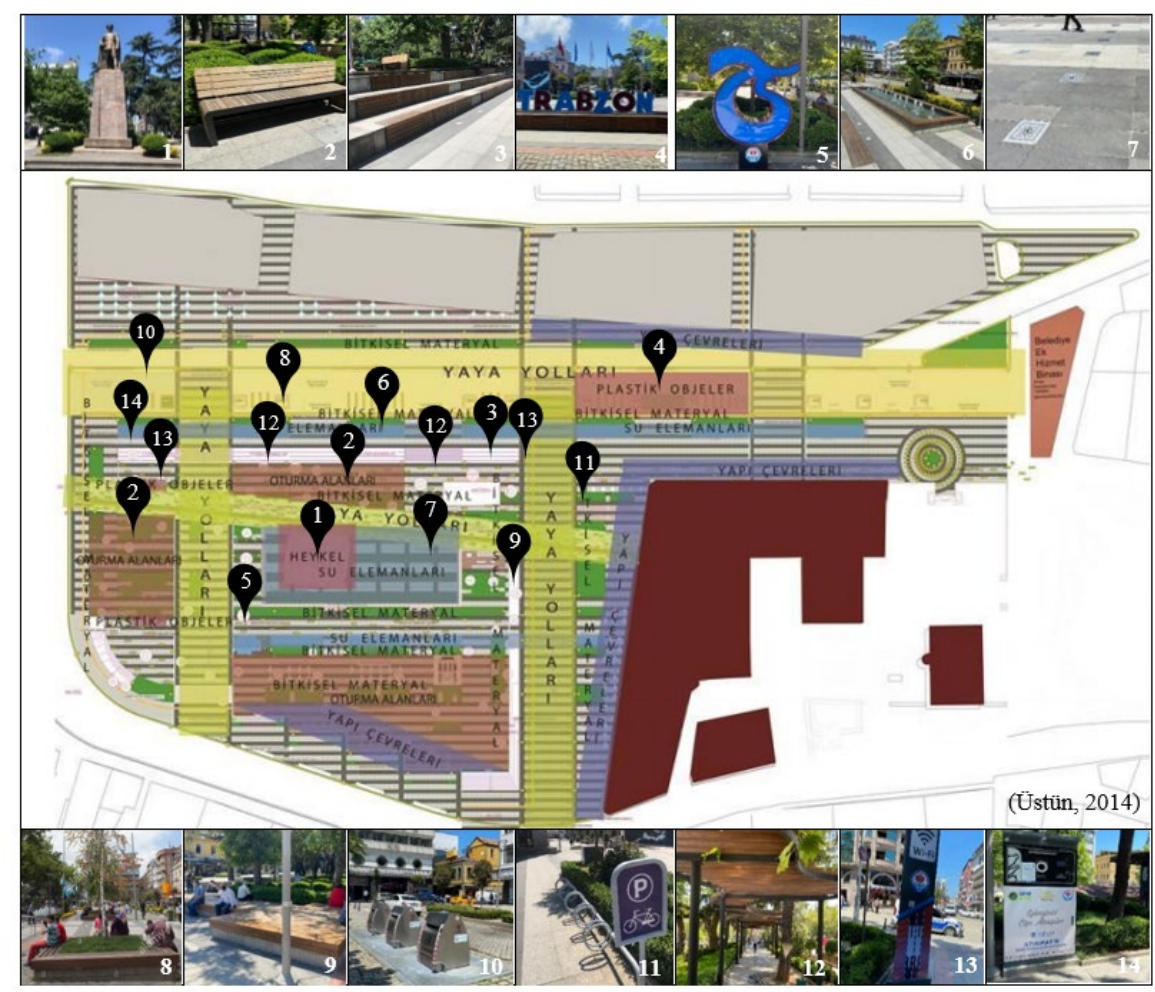

Şekil 5. Kent donatılarının Meydan Parkı'ndaki konumları

\section{Oturma elemanlar1}

Tip 1: Bank biçiminde tasarlanan oturma elemanı çoğunlukla ağaçların etrafında konumlanmaktadır. Park içerisinde taşınabilir tek oturma elemanıdır.

Tip 2: Basamak düzeni şeklinde kurgulanan ve dinlenmeye imkân tanıyan oturma elemanı, aynı zamanda sosyal aktiviteler gerçekleşirken sahne karşısındaki bir tribün görevi de görmektedir.

Tip 3: Bu tipteki oturma elemanları çeşme ve ağaç etrafında tam tur dönecek şekilde kurgulanmıştır. Böylelikle oturma elemanları hem görsel sınır oluşturmakta hem de park ziyaretçilerine doğa ile yakın temas olanağı sağlamaktadır.

Tip 4: Parkta sadece bir adet bulunan oturma elemanı sabit bir donatı olup asimetrik forma sahip bütüncül bir yaklaşımla tasarlanmıştır.

\section{Cöp kutular1}

Tip 1: Çöp kutusu ebat olarak küçük ve tek bölmelidir.

Tip 2: Diğer tiplerdeki çöp kutuları metal malzemeden oluşurken, tip 2'deki çöp kutuları metal ve ahşap malzemenin birleşiminden oluşmaktadır. Ayrıca çöp kutularının iki bölme olarak tasarlanması atıkların ayrışımını sağlayarak geri dönüşüme katkı sağlamaktadır. Park içerisinde sayıca en çok bulunan çöp kutusu tipidir.

Tip 3: Aydınlatma elemanları direkleri üzerine yerleştirilen bu tipteki çöp kutuları diğer tiplere ait çöp kutularına nazaran daha yüksekte konumlanmaktadır.

Tip 4: Park içerisinde bu tipe ait 3 adet çöp kutusu bulunmaktadır. Ayak ile basılarak açılan çöp kutuları yer altında büyük bir atık birikim alanına sahiptir. 


\section{Aydinlatma elemanları}

Tip 1: Park içerisinde tek tip aydınlatma elemanı kullanılmaktadır. Aydınlatma elemanları sirkülasyon hattı üzerinde belirli aralıklarla konumlandırılmaktadır.

Tip 2: Bu tip hava karardığında devreye giren aydınlatma elemanlarını içermektedir. Su öğelerinin içerisinde, Atatürk Heykeli'nin etrafında konumlandırılan aydınlatmalar vurgu amaçlı kullanılmaktadır.

Tip 3: Zemin içerisine yerleştirilen aydınlatmalar hava karardığında devreye girmektedir.

\section{Döșeme}

Tip 1: Park yenilendikten sonra kullanılan gri tonlarındaki döşeme ve aralarına yerleştirilen görme engelli bireylerin daha rahat ve kolay hareket etmelerini sağlayan polimer esaslı zemin malzemesi bu tip içerisinde yer almaktadır.

Tip 2: Eski yıllardan itibaren korunarak gelen arnavut kaldırımı taşlar parkın küçük bir bölümünü oluşturmaktadır.

\section{Bilgi ve yönlendirme levhaları}

Tip 1: Bu tip parkta yer alan bisiklet park alanını işaret eden bilgi levhalarını içermektedir.

Tip 2: Parkta tek adet bulunan bilgilendirme levhası parkın adına dair bilgilendirmede bulunmaktadır.

Tip 3: Bu tip park içerisinde yer alan satış ve hizmet birimlerinin isimlerini içermektedir.

\section{$\underline{\text { Su öğeleri }}$}

Tip 1: Dikdörtgen forma sahip olan su öğeleri park içerisinde ara ara yer almaktadır. Belirli saatlerde içerisine yerleştirilen su fiskiyeleri ile birlikte su içerisinde görsel hareketlilik sağlanmaktadır.

Tip 2: Atatürk heykelinin önünde yer alan su öğeleri döşeme üzerine belirli aralıklarla yerleştirilmiştir. Belirlenen zamanlarda, bu elemanlardan yukarıya doğru su yükselerek kullanıcıların ilgisini çekmektedir.

Tip 3: Parkın girişine yakın olarak konumlanan çeşme parkta tek adet bulunmaktadır.

\section{Atatürk heykeli}

Tip 1: Meydan Parkı'nın merkezine yerleştirilen Atatürk Heykeli hem parkın odak noktası hem de sosyal ve siyasi aktivitelerin merkezi görevindedir.

\section{$\underline{\text { Simgesel objeler }}$}

Tip 1: Son birkaç yıldır park içerisinde yerini alan Trabzon yazısı turistlere fotoğraf çekimi için imkân sunmaktadır.

Tip 2: Kent için kimlik değeri yüksek olan spor kulübü Trabzonspor amblemi bu tip içerisinde yer almaktadır. Hava karardığında amblem aydınlatma elemanlarına yardımcı bir unsur olmaktadır.

\section{Üst örtü öğeleri}

Tip 1: Parkın sadece 2 yerinde yer almaktadır. Organik forma sahip olan üst örtü elemanları işlevsel olarak görev yapmaktan ziyade ahşap görünümü estetik açıdan parka uyum sağlamaktadır.

\section{Diğer öğeler}

Parkta sınıflandırılması yapılan kentsel donatılar haricinde bazı elemanlarda yer almaktadır. Bunlar wi-fi erişim noktası, atıkmatik ve bisiklet park alanlarıdır. Park içerisindeki yardımcı elemanlar ile (wi-fi vb. gibi) insan gücü azaltılarak, kullanıcıların teknolojik gereksinimlerine hizmet edilmektedir. Geri dönüşüme teşvik etmek amaçlı 
kullanıcılara hizmet eden atıkmatik park içerisinde tek adet bulunmaktadır. Ayrıca parkın sonunda bisikletlerin park alanlarının bulunduğu bölge yer almaktadır.

\subsection{Anket verilerine yönelik bulgular}

Anket çalışması sonucunda elde edilen bulgular ve değerlendirmeler bu başlık altında sunulmaktadır. Kullanıcılar ile yapılan anket çalışması verilerinin, tablolar ve grafikler üzerinden yorumlamaları yapılmaktadır. Araştırmada öncelikle örneklem alanlardaki kullanıcılarını sosyo-demografik özelliklerine görece genel profilleri belirlenerek aşağıdaki sonuçlara ulaşılmıştır (Tablo 2).

Tablo 2. Anket çalışmasına katılan kişilerin sosyo-demografik özellikleri

\begin{tabular}{|l|l|c|c|}
\cline { 3 - 4 } \multicolumn{2}{c|}{} & $\mathrm{n}$ & $\%$ \\
\hline \multirow{3}{*}{ Cinsiyet } & Kaşı & 88 & 47,5 \\
\cline { 2 - 4 } & Erkek & 97 & 52,5 \\
\hline \multirow{4}{*}{ Eğitim durumu } & 25 yaş ve altı & 14 & 7,5 \\
\cline { 2 - 4 } & $25-45$ & 78 & 42,3 \\
\cline { 2 - 4 } & 45 yaş ve üstü & 93 & 50,2 \\
\cline { 2 - 4 } & İlkokul & 4 & 2,2 \\
\cline { 2 - 4 } & Lise & 30 & 16,2 \\
\cline { 2 - 4 } & Üniversite & 151 & 81,6 \\
\hline & TOPLAM & 185 & 100 \\
\cline { 2 - 4 } & & & \\
\cline { 2 - 4 }
\end{tabular}

Kullanıcılarının sosyo-demografik özelliklerinden cinsiyet, yaş, eğitim bilgileri istatiksel olarak Tablo 2'de verilmektedir. Araştırmanın örneklemi, 88'i kadın 97'si erkek olmak üzere 185 kișiden olușmaktadır. Bunlar arasından; 14'ü $(\% 7,5) 25$ yaş altı, 78'i $(\% 42,3) 25$ ve 45 yaş aralığında ve 93 'ü $(\% 50,2) 45$ yaş ve üzerindedir; 4'ü $(\% 2,2)$ ilkokul, 30’u $(\% 16,2)$ lise ve 151'i $(\% 81,6)$ üniversite seviyesinde eğitim düzeyine sahiptir.

Katılımcılara, Meydan Parkı'nı kullanma sıklığı sorulduğunda; 36'sı (\%20) her zaman, 72'si (\%39) sıklıkla, 41'i (\%22) ara sıra, 30’u (\%16) nadiren kullandığını ve 6'sı (\%3) hiç kullanmadığını belirtmiştir (Şekil 6). Bu verilerden hareketle katılımcıların büyük bir çoğunluğunun Meydan Parkı'nı kullandığı görülmektedir.

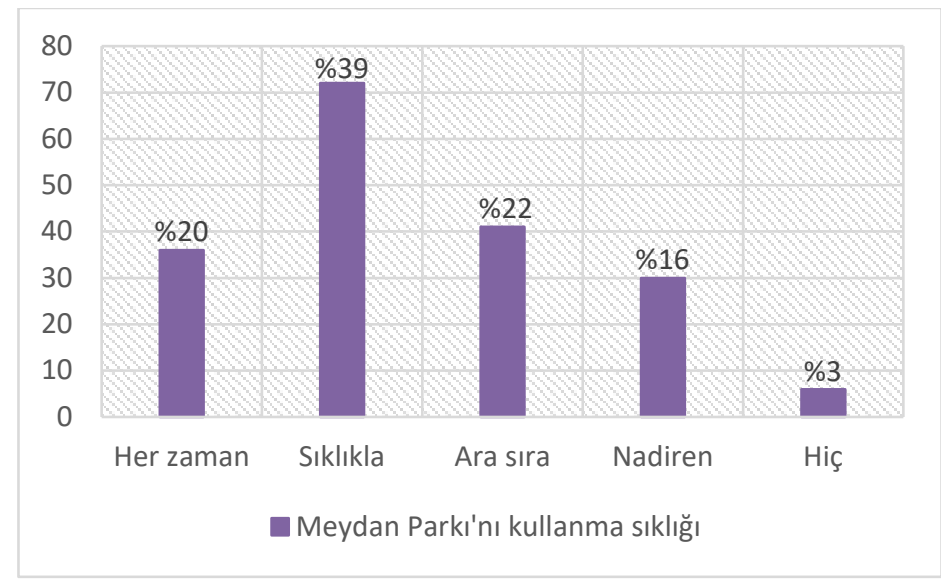

Şekil 6. Meydan Parkı’nın kullanım sıklı̆̆ı

Anketin bir diğer sorusu katılımcıların Meydan Parkı'nı hangi amaçla kullandıklarının belirlenmesine yöneliktir. Bu soruyu toplam 185 kişi cevaplamıştır. Katılımcılardan 42'si (\%23) Meydan Parkı'nı çay bahçesi, 73'ü (\%39) oturma ve dinlenme, 106'sı (\%57) buluşma noktası, 7'si (\%4) konser, 21'i (\%11) siyasi toplantılar/miting, 98'i (\%53) geçiş 
mekânı, 35’i (\%19) gezme, 11'i (\%6) WC kullanma, 17'si (\%9) lostra amaçlı kullanmaktadır (Şekil 7). 11 kişi ise diğer seçeneğini işaretleyerek "Atatürk'ü ziyaret etme, fatura ödeme" gibi amaçlarla kullandığını belirtmiştir. Diğer seçeneklere göre "buluşma noktası" ve "geçiş mekânı" amaçlı kullanımlar belirgin bir şekilde ön plana çıkmaktadır. Bu da Meydan Parkı'nın konum olarak merkezi bir noktada olması ile açılanmaktadır. Bu iki kullanım amacının hemen ardından ise oturma/dinlenme seçeneği gelmektedir. Meydan Parkı'nın neredeyse her yerinde farklı tiplerde oturma donatılarının bulunması ve kent sakinlerine sosyalleşme imkânı sunması insanların Meydan Parkı'nı tercih etme nedenleri arasında yer almaktadır.

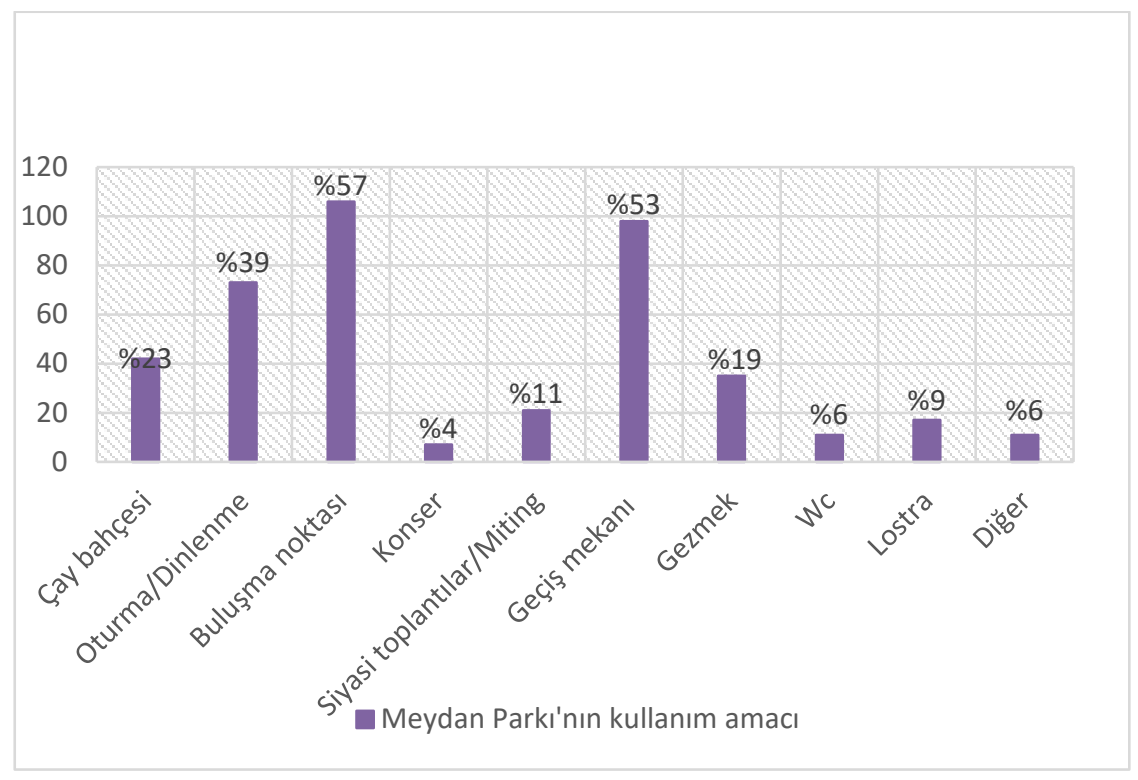

Şekil 7. Meydan Parkı'nın kullanım amacına yönelik sorulara verilen cevaplar

Anketin sonraki sorusunda katılımcılardan Meydan Parkı'nda akıllarında kalan kent donatılarını, yer-bellek-kimlik ilişsisini kurmak için yazmaları istenmiş ve nedenleri sorulmuştur. Bu soruyu toplam 185 kişi cevaplamıştır. 82 kişi (\%45) Atatürk heykeli cevabını vererek "konum olarak parkın merkezinde bulunması, park içinde tarif etmek için kullanılan bir işaret öğesi oluşu, etkinliklerin heykel çevresinde gerçekleşmesi, boyutları, dikkat çekici oluşu" olduğunu belirtmiştir. 37 kişi (\%20) Trabzonspor Heykeli cevabını vererek ve "Trabzonspor'un Trabzon için önemli bir imge olması, fotoğraf çekilmek için, göze çarpması" gibi sebepler belirtmiştir. 31 kişi (\%16) oturma elemanları cevabını vererek "ağaçların korunarak bankların düzenlenmesi, ağaçların gölgelediği alanlarda oturma keyfi sunması, park içinde birçok yerde sosyal alanlar sunması, esnek kullanım alanları sunması" gibi sebepler belirtmiştir. 19 kişi (\%10) su öğeleri (havuzlar, su fiskiyesi, çeşme) cevabını vererek "görsel açıdan güzel ve ferahlık etkisi vermesi, dinlendirici olması" gibi sebepler belirtmiştir. 13 kişi (\%7) Trabzon yazısı Heykeli cevabını vererek "fotoğraf çekilme noktası olması ve dikkat çekici olması" gibi sebepler belirtmiştir. 11 kişi (\%6) aydınlatma veya aydınlatma elemanları cevabını vererek "Işıkların geceleri görsel açıdan etkileyici ve dikkat çekici olması" gibi sebepler belirtmiștir. 5 kiși (\%2) çöp kutuları cevabını vermiş ve özellikle tip 4 çöp kutusundan bahsederek "yerin altında yapılan çöp kutularının dikkat çekici” olduğunu belirtmiştir.

Katılımcılardan Meydan Parkı'nda bulunan kent donatılarının mekan kimliğine kattığı değeri ile 1-5 arasında (1=mekan kimliğine katkısı yoktur, $2=$ mekan kimliğine az katkısı vardır, $3=$ mekan kimliğine orta düzeyde katkısı vardır, $4=$ mekan kimliğine katkısı vardır, $5=$ mekan kimliğine yüksek düzeyde katkısı) değerlendirmeleri istenmiştir. Sonuçlar değerlendirildiğinde parkta bulunan heykellerin diğer kent donatılarına oranla daha fazla puanlandı $\breve{g ̆}_{1}$ ve bunlar arasında özellikle Atatürk Heykeli'nin belirgin bir şekilde ön plana çıktığı görülmektedir. 1 ile 5 arası değerlendirilen kent donatılarının aritmetik ortalaması alınmıştır. Anket verilerinden hareketle katılımcılara göre park için kimlik unsuru olma durumu çoktan aza doğru sırasıyla heykeller (Atatürk Heykeli) $(4,54)$, simgesel objeler (Trabzonspor amblemi, Trabzon yazısı) $(4,2)$, su öğeleri $(3,35)$, aydınlatma elemanları $(3,27)$, oturma elemanları $(3,24)$, döşeme $(3,02)$, bilgi ve yönlendirme levhaları $(3,02)$, çöp kutuları $(2,73)$, üst örtü öğeleri $(1,8)$ olarak ortaya çıkmıştır (Şekil 8). Sonuçlar incelendiğinde ilk sıralarda çıkan 
Atatürk Heykeli ve Trabzonspor Heykeli'nin önceki soruya verilen yazıll cevaplarla örtüştüğü görülmektedir. Bu nedenle bu öğelerin parkta en fazla akılda kalan ve kimlik kazandıran öğeler olduğunu söylemek mümkündür.

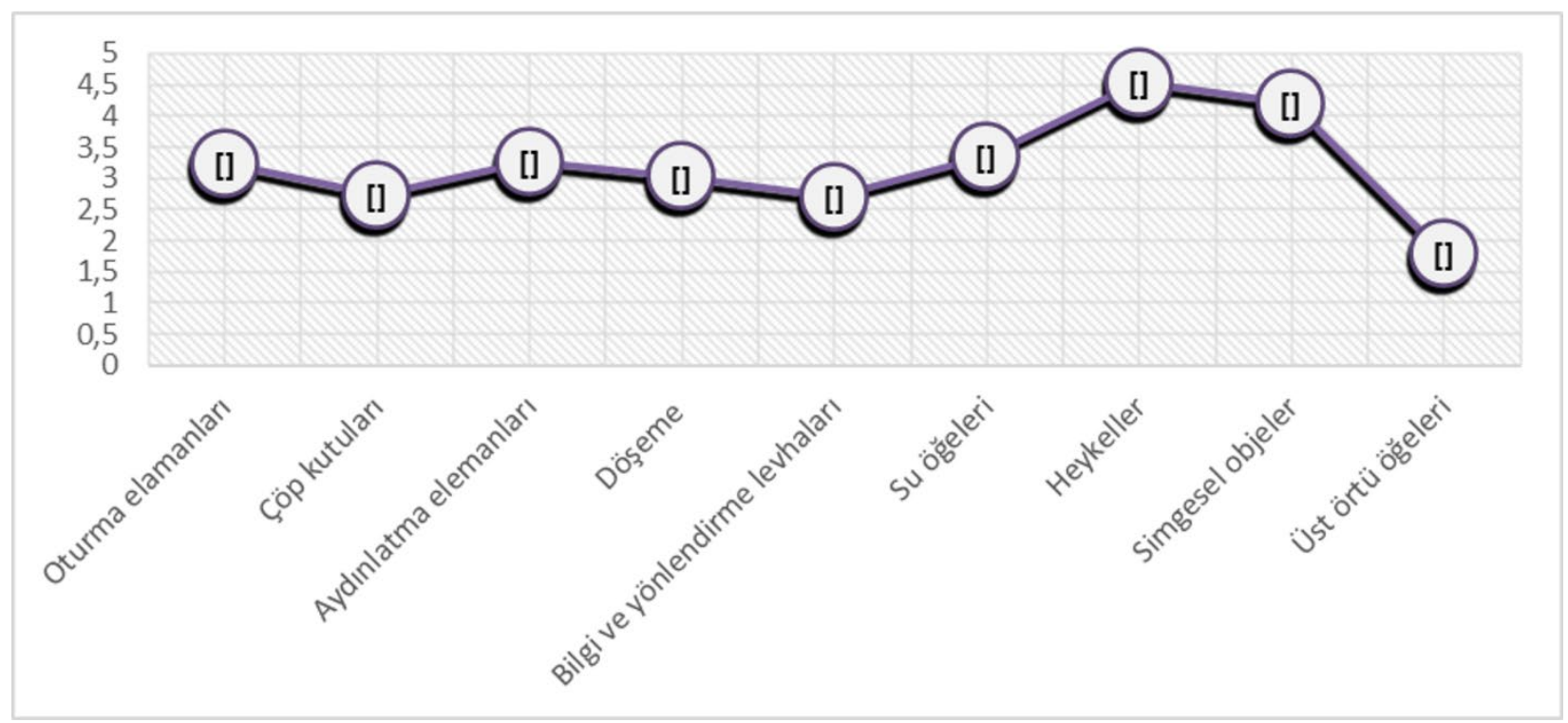

Şekil 8. Meydan Parkı'nda bulunan kent donatılarının mekân kimliğine kattığı değere yönelik sonuçlar

\section{SONUÇ:}

Kentsel mekanlar kullanıcının deneyimleri, alışkanlıkları, günlük pratikleri, sosyo-kültürel özellikleri gibi çeşitli faktörlerden etkilenerek her birey için farklı anlamları ifade eder. Bu mekanlar bireyin zihin süzgecinden geçerek farklı imgelerde karşılık bulur. Kent donatıları ise kentsel mekanların hafızada yer edinmesinde ve mekânı tanımlamasında önemli aracılardan biridir. Kent donatılarının mekânı tariflemedeki önemini ve zihindeki yerini sorgulayan bu çalışmada edinilen sonuçlar aşağıda sıralanmıştır;

- Kentsel mekanların tanımlanmasında, okunaklığının ve algılınabilirliğinin artmasında önemli bir yere sahip olan kent donatıları zamanla bir imge haline gelerek bireylerin biliş haritalarında yer edinmektedir. $\mathrm{Bu}$ doğrultuda kent mobilyaları kimi zaman taşıdığı fiziksel özellikleri ile kimi zaman da anlamsal değeri veya anı niteliği ile ön plana çıkmaktadır.

- Kent donatıları konumlandığı mekanda, çevresiyle uyumlu görsel bir bütünlük oluşturmalı ve ihtiyaçlara cevap verebilir nitelikte tasarlanmalıdır. Bu özellikleri ile kent donatısı; bulunduğu mekanda bir imge olarak ön plana çıkabilmekte ve bulunduğu mekanı tanımlayarak oraya özgü bir imge olarak akılda yer edinebilmektedir.

- Meydan Parkı, kent sakinleri tarafından çeşitli amaçlarla kullanılan ve konumu itibariyle sıklıkla ziyaret edilen bir mekandır. Parkın çeşitli imkanlarla kullanılıyor olması parkın ve içinde barındırdığı kent donatılarının kullanımını ve bilinirliğini arttırmıştır. Bir mekanın veya donatının kullanım sıklığı zihin haritalarının oluşmasında önemli bir etkendir.

- Meydan Parkı, merkezi konumu nedeniyle çoğunlukla geçiş mekanı veya buluşma mekanı olarak kullanılmaktadır. $\mathrm{Bu}$ durum kullanıcının yaya olarak hareket ettiği mekanları daha iyi tanımasına ve kavramasına imkan tanımaktadır. 
- Meydan Parkı'nda yapılan çeşitli aktiviteler kent mobilyalarının kullanımını arttırmakta ve bireylerin orada yaşadığı anılar ile birlikte zihinlerde yer edinmektedir.

- Meydan Parkı'nda Atatürk Heykeli, Trabzon yazısı ve Trabzonspor amblemi diğer kent donatılarına göre daha belirgin olarak ön plana çıkarak, Meydan Parkı ile özdeşleştiği görülmektedir. Bu verilerden hareketle kişilerin biliş haritalarında anlamsal ve simgesel öğelerin daha baskın olduğunu söylemek mümkündür.

- Meydan Parkı'nda yer alan su öğeleri (havuz, fiskiyeler vb.) bireylerin zihninde yer edinen bir diğer kent donatılarıdır. Buradan yola çıkarak kent sakinlerinin bir mekanda işlevsel gereksinimlerin yanında görsel ve estetik algıya da önem verdiklerini ve tercih sebebi olduğunu söylemek mümkündür. Estetik ve görsel özellikler kent donatılarının bir imge olarak ön plana çıkmasında ve zihinde yer edinmesinde önemli özelliklerdir.

- Kent donatıları arasında mekana özgü donatılar daha fazla ön plan çıkarken her yerde rastlanabilen, sıradan donatıların bireylerin zihinlerinde yer edinmediği görülmektedir.

- Meydan Parkı'nda oturma, aydınlatma, yönlendirme gibi temel ihtiyaçların yanında internet erişimi, şarj noktaları gibi alternatif hizmetlerin sağlandığı kent donatılarının bulunması mekanın tercih edilebilirliğini arttırmakta ve mekana kimlik kazandırmaktadır.

- Kentsel alanlarda kimliğin oluşmasında etkili bir unsur olan kent donatıları hem görsel hem de işlevsel yönüyle okunaklı ve algılanabilir bir şekilde tasarlanmalı ve konumlanmalıdır.

Sonuç olarak; kent donatılarının, bireylerin bilişsel haritasında mekânı tanımlayan ve kimlik kazandıran önemli bir imaj öğesi olduğu görülmektedir. Kente ve kent imajına katkısı göz önünde bulundurularak, kent donatı elemanlarının 'mekâna özgü’, 'mekân için', ‘özelleşmiş', ‘özgün' olarak tasarlanması, konumlanması, korunması ve iyileştirilmesinin mekana kimlik kazandırmak ve akılda kalıcılığı sağlamak açısından önemli olduğu görülmüştür.

\section{Etik Standart ile Uyumluluk}

Çıkar Çatışması: Yazarlar herhangi bir çıkar çatışmasının olmadığını beyan eder.

Etik Kurul İzni: Bu çalı̧̧ma için etik kurul iznine gerek yoktur.

Finansal Destek: Yoktur.

Teşekkür: Yoktur

\section{KAYNAKÇA:}

Aksu, Ö. V. (2012). Kent mobilyaları tasarımında özgün yaklaşımlar. İnönü Üniversitesi Sanat ve Tasarım Dergisi, 2(2), 373-386.

Altman, I. \& Chemers M. (1980). Culture and Environment, Environmental Cognition and Perception, Wadsworth Inc., 43-71.

Arruda A., Moroni I., Bezerra P., Silva P. \& de Paiva RBF (2017) Practical urban: the urban furniture and its relationship with the city. İçinde: Soares M., Falcão C., Ahram T. (eds) Ergonomi Modelleme, Kullanılabilirlik ve Özel Popülasyonlardaki Gelişmeler. Akıllı Sistemler ve Hesaplamadaki Gelişmeler, cilt 486. Springer, Cham,

s. 413-423. https://doi.org/10.1007/978-3-319-41685-4_37 
Aykut, F. (1997). Dış mekân kentsel donatı elemanlarında ahşap malzeme kullanımı: Bartın belediye parkı örneği, (Yayınlanmamış yüksek lisans tezi). Zonguldak Karaelmas Üniversitesi, Fen Bilimleri Enstitüsü, Bartın.

Bayrakçı, O. (1991). Kent Mobilyaları Tasarımında Kimlik Sorunu ve Kent Kimliği İçindeki Yeri. Kamu Mekanları Tasarımı ve Kent Mobilyaları Sempozyumu, Mimar Sinan Üniversitesi, İstanbul, 75-79.

Bayraktar, N., Tekel, A. \& Yalçıner Ercoşkun, Ö. (2013). Ankara Atatürk bulvarı üzerinde yer alan kentsel donatı elemanlarının sınıflandırılması, değerlendirilmesi ve kent kimliği ilişkisi. Gazi Üniversitesi Mühendislik Mimarlık Fakültesi Dergisi, 23(1), 105-118.

Bayramoğlu, E. \& Yurdakul, N. (2019). Kentsel açık mekân olarak meydanların yaşam kalitesine etkileri: Trabzon örneği. Tarih Kültür ve Sanat Araştırmaları Dergisi, 8(1), 425-435.

Bekar, İ. \& Ertaş Beşir, Ş. (2021). The Place of Urban Furniture in The Formation of Historical Environmental Identity. Boyko RANGUELOV Zharas G. BERDENOV Recep Efe (Ed.), Advances in Scientific Research: Engineering and Architecture içinde (223-238). ST: Klıment Ohrıdskı Unıversıty Press.

Celbiş, Ü. (2001). Ürün Kullanıı İlişkileri Bağlamında Kent Mobilyaları ve İşlevleri. 1.Uluslararası Kent Mobilyaları Sempozyuтu, İstanbul Büyükşehir Belediyesi, İstanbul,175-178.

Çanakçıŏlu, N.G. (2011). İstanbul'da farklı sosyal grupların yerleştiği çevrelerde yaşayan çocukların algısal süreçlerinin bilişsel haritalar yöntemiyle irdelenmesi, (Yayınlanmamış yüksek lisans tezi). İstanbul Teknik Üniversitesi, Fen Bilimleri Enstitüsü, İstanbul.

Çınar, H. S. , \& Cermikli, B., (2019). Poınt Densıty Analysıs Wıth Cognıtıve Mappıng Technıque: Istanbul-Hıstorıcal City Center. Fresenıus Environmental Bulletın, Vol.28, 9192-9199.

Çubuk M. (1991). Kamu Mekânları ve Kentsel Tasarım', Kamu Mekânları Tasarımı ve Kent Mobilyaları Sempozyumu 15-16 Mayıs 1989, İstanbul, M.S.Ü./ Mimarlık Fakültesi, 15-17.

El-Ghonaimy, I. H. (2020). Street Furniture Influence in Revitalizing the Bahraini Identity. Journal of contemporary urban affairs, 4(1), 11-20.

Eray, S. S. \& Kutlu, İ. (2021). Anadolu'da Selçuklu ve Osmanlı kent yapısında çarşının konumu ve mekânsal kurgusu üzerine bir İrdeleme. Kent Akademisi, 14(2), 506-517.

Ertaş, S.., Kurak Açıcı, F., Özdemir, İ., Koç, S. \& Köse, O. (2017). Konya/Sille Hükümet Caddesi Mevcut Kent Bileşen ve Öğelerinin Tespiti, Kent Mobilyasıyla Anlatılan Tarih Konya/Sille (Ed:Şebnem Ertaş), Ankara: Detay Yayıncilik.

Gattis, M. (2001). Space as a Basis for Abstract Thought, Spatial Schemas and Abstract Thought. London, UK: MIT Press.

Gür, Ş. Ö. (1996). Mekan Örgütlenmesi, Trabzon: Gür Yayınları.

Huff, A. S. (2002). Mapping Strategic Knowledge. London: Sage Publications Incorporated.

Jacobson, J. L., (1998). Cognitive Mapping Without Sight: Four Preliminary Studies of Spatial Learning, Journal of Environmental Psychology, 18, 289- 305.

Kurdoğlu, B. Ç., Aktürk, E. \& Kurt K. S. S. (2018). Trabzon kent parkları üzerine genel bir inceleme. 2. Uluslararası Bilimsel Çalışmalarda Yenilikçi Yaklaşımlar Sempozyumu, Samsun.

Lloyd, R. (2000). Self-Organized Cognitive Maps, Professional Geographers, 52(3), 517-531.

Lynch, K. (1960). The image of the city, Cambridge: The M.I.T Press. 
Mellado, V. (1997). Preservice teachers' classroom practice and their conceptions of the nature of science. Science \& Education, 6, 331-354.

Miles, M. B. \& Huberman, A. M. (1994). Qualitative data analysis: An expanded sourcebook (2nd ed.). Thousand Oaks, CA: Sage.

Moore, G. T. \& Golledge, R. G. (Eds.). (1976). Environmental knowing: Theories, research and methods. Dowden.

Özaydın, G., Erbil, D. \& Ulusay, B. (1991). Kamu mekanları tasarımının tamamlayıcısı olarak, bildirişim öğeleri, Kamu Mekanları Tasarımı ve Kent Mobilyaları Sempozyumu, İstanbul.

Özdağoğlu, A. (2010). Bilişsel Haritalama ve Analitik Serim Süreci (ASS) Entegrasyonu. Yönetim ve Ekonomi Dergisi , 17 (1), 1-10.

Özdemir, M. İ., Ural, E. S. \& Gür, Ö. Ş. (1991). Yap1 bileşen ve öğelerinin mekan örgütlenmesine etkileri, Uluslaraarası II. Yapı ve Yaşam Kongresi, Bursa, 158-174.

Öztürk, Ç. A. (2017). Eskişehir'in Geçmişteki ve Bugünkü Kent Belleğinin Zihin Haritaları Üzerinden Okuma Denemeleri. Kent Araştırmaları Dergisi, 20(7), 856-880.

Sanoff, H. (1991). Visual Research Methods in Design. Newyork.

Strati, A. (1998). (Mis) Understanding Cognition In Organization Studies, Scandinavian Journal of Management, 14(4), 317.

Südaş, İ. \& Öz, İ. (2018). Davranışsal coğrafyada bilişsel haritalar: Ege Üniversitesi kampüsü örneği. Türk Coğrafya Dergisi, 71, 81-92.

Topçu, K.D. \& Topçu, M. (2012). Visual presentation of mental images in urban design education: cognitive maps. Selcuk University, Faculty of Eng.\& Architecture, Department of Urban and Regional Planning.

Türk, S. (2017). Beypazarı kent kimliğinin bilişsel haritalama yöntemi ile değerlendirilmesi. Mehmet Akif Ersoy Üniversitesi Sosyal Bilimler Enstitüsü Dergisi, 9(19), 483-499.

URL-1, (2021). https://tr.depositphotos.com/stock-photos/eski-k\%C4\%B1rm\%C4\%B1z\%C4\%B1-telefonkutusu.html_(Erişim tarihi 01.06.2021).

URL-2, (2021). https://arttenders.com/blog/2017/06/the-10-most-inspiring-art-in-subway-stations/ (Erișim tarihi $\underline{01.06 .2021)}$.

URL-3, (2021). https://pxhere.com/en/photo/901261 (Erișim tarihi 01.06.2021).

URL-4, (2021). https://www.neredekalmistikmag.com/post/prag-astronomik-saat-kulesi-prag-orloj (Erișim tarihi 01.06.2021).

Ülkeryıldız, E., Durmuş Arsan, Z. \& Akış, T., (2009). Öğrenci zihin haritalarında kente ilişskin deneyimle değişen çevre alglsı. Balıkesir Üniversitesi Fen Bilimleri Enstitüsü Dergisi, 11(1), 72-82.

Üstün, T. (2014). Kentsel park aydınlatmalarının kullanıcı açısından değerlendirilmesi: Trabzon kenti Meydan Parkı ve Atapark örnekleri (Yüksek lisans tezi). Karadeniz Teknik Üniversitesi, Fen Bilimleri Enstitüsü, Trabzon.

Yaylalı, S. (1998). Kent mobilyaları tasarımında kullanılabilecek kavramsal bir model. (Yayınlanmamış yüksek lisans tezi). İstanbul Teknik Üniversitesi, Fen Bilimleri Enstitüsü, İstanbul.

Yıldızcı, A. C. (2001). Kent Mobilyaları Kavramı ve İstanbul'daki Kent Mobilyalarının İrdelenmesi, I. Uluslararası Kent Mobilyaları Sempozyumu, Bildiriler Kitabı, 29-34. 